Jurnal Independent Fakultas Hukum

\title{
TINDAK PIDANA PENCEMARAN NAMA BAIK MELALUI MEDIA SOSIAL TINJAUAN PUTUSAN PENGADILAN TINGGI NOMOR 487/PID.SUS/2017/PT.MDN
}

\author{
Hadziqotun Nahdliyah, SH, MH. \\ Fakultas Ilmu Hukum, Universitas Islam Lamongan \\ Jalan Veteran No.53A, Lamongan. \\ Lia.asyari@ymail.com
}

\begin{abstract}
ABSTRAK
Perkembangan teknologi informasi yang semakin cepat, mudah dan canggih memliki peran penting dalan bidang pekerjaan dan komunikasi online. Salah satu manfaat komunikasi online adalah dengan munculnya beragam situs pada media sosial. Media sosial dianggap tempat paling mudah untuk mengakses berita, mengedit, atau menambahkan baik tulisan, gambar atau video dan lain-lainnya dengan tidak membutuhkan alat dan biaya yang besar. Pengguna media sosial yang dimudahkan dalam membuat opini atau pendapat hanya dengan memposting di akun yang dimiliki menjadikan penyalahgunaan bagi sebagian orang terutama dalam hal pencemaran nama baik.Metode penelitian yang digunakan dalam penelitian ini adalah yuridis normatif, yaitu penelitian yang difokuskan pada penerapan kaidah-kaidah atau norma-norma dalam hukum positif dan pendekatan penelitian yang digunakan adalah pendekatan perundang-undangan (statue approach). Bahan hukum yang digunakan Undangundang Dasar Negara Republik Indonesia Tahun 1945, Kitab Undang-undang Hukum Pidana, Undang-undang Nomor 11 Tahun 2008 tentang Informasi dan Transaksi Elektronik dan Putusan Pengadilan Tinggi Nomor 487/Pid.Sus/2017/PT.MDN.Hasil penelitian menunjukkan bahwa penegakan hukum dalam tindak pidana pencemaran nama baik telah diatur dalam Kitab Undang-undang Hukum Pidana pada Pasal 310 ayat (1) dan (2) juga telah diatur di dalam Undang-undang Nomor 11 Tahun 2008 tentang Informasi dan Transaksi Elektronik pada Pasal 27 ayat (3) dan Pasal 28 ayat (2). Dan hasil pertimbangan hukum hakim dalam memutus perkara banding tindak pidana pencemaran nama baik dalam kasus tersebut adalah menguatkan putusan Pengadilan Negeri sebelumnya yang dimintai banding melalui pertimbangan berdasar alat bukti yang sah dan azas keadilan, kepatuhan dan kemanfaatan.
\end{abstract}

\section{Kata kunci : Tindak Pidana, Pencemaran Nama Baik, Media Sosial.}

\section{PENDAHULUAN}

Perkembangan teknologi informasi yang semakin canggih, mudah dan cepat mengakibatkan pengaruh yang besar bagi kehidupan manusia pada jaman sekarang tak terkecuali masyarakat indonesia. Di era globalisasi tentu teknologi informasi berperan penting dalam banyak hal contohnya dalam bidang pekerjaan dan komunikasi online. Salah satu manfaat dari teknologi informasi adalah munculnya beragam situs pada jejaring sosial (sosial media).

Sosial media adalah alat dimana para penggunanya bisa saling berkomunikasi dan berinteraksi secara online melalui jaringan internet. Beragam media sosial seperti path, twitter, instagram, snapgram, facebook, dan lain-lain mengakibatkan banyak pengguna bingung karena banyaknya pilihan pada media sosial akan tetapi pada intinya semua situs media sosial 
Jurnal Independent Fakultas Hukum

adalah untuk komunikasi online. Dengan mudah banyaknya akses pada media sosial menjadikan penggunanya bukan hanya anak muda saja akan tetapi menyebar luas hingga orang tua atau bahkan dari segala umur. Pada zaman sekarang media sosial seakan menjadi candu atau bisa dibilang menjadi kebutuhan pokok untuk sebagian orang yang mana akan merasa aneh bila tidak membuka situs jejaring sosial dalam sehari.

Kemajuan pada internet dan mobile phone membuat media sosial bertumbuh dengan pesat. Kini semua orang bisa mengakses media sosial dimanapun mereka berada dengan menggunakan mobile phone. Karena kecanggihan dan kecepatannya media sosial juga beralih fungsi yang tadinya hanya untuk berkomunikasi online sekarang media sosial juga digunakan untuk menyebarkan berita-berita. Dahulu untuk memperoleh berita orang-orang menggunakan media televise atau koran yang mana dianggap tidak lagi efisien untuk era sekarang.

Media sosial dianggap sebagai tempat yang paling mudah untuk mengakses berita bahkan sebagian orang mulai memilih menulis berita menggunakan salah satu dari jejaring situs pada media sosial yang mana tidak membutuhkan alat yang mahal dan biaya yang besar. Semua pengguna media sosial juga bisa mengedit atau menambahkan baik itu tulisan, gambar atau video dan lainlainnya. Kita sebagai pengguna media sosial dimudahkan dengan ketika mau membuat opini atau pendapat tentang suatu hal tidak perlu untuk memuatnya di koran ataupun majalah karena media sosial sudah mewadahi itu semua. Akan tetapi dengan mudahnya memberikan opini yang menjadikan penyalahgunaan bagi sebagian orang mulai dari menyebarkan berita bohong, pencemaran nama baik ataupun untuk menjatuhkan orang lain.

Dalam kehidupan sehari-hari diberbagai bidang masyarakat Indonesia juga tidak lepas dari aspek positif dan aspek negatif di dunia media sosial sesuai dengan perkembangan teknologi informasi. Sebagai negara hukum yang sudah tercantum dalam Pasal 1 ayat (3) hasil amandemen ke-empat Undang-Undang Dasar 1945 yang menyatakan "Negara Indonesia adalah Negara hukum" yang berarti semua aspek kehidupan baik dibidang sosial, politik, ekonomi dan budaya diatur dan dibatasi oleh normanorma hukum yang berlaku .

Belakangan ini masalah hukum pidana yang paling sering disoroti adalah tentang tindak pidana pencemaran nama baik. Dikarenakan banyaknya kasus-kasus yang bermunculan tentang pencemaran nama baik terutama pada jejaring media 
sosial. Pencemaran nama baik umumnya merupakan delik. Seseorang yang nama baiknya dicemarkan bisa melakukan tuntutan di pengadilan negeri sipil dan jika menang bisa mendapatkan ganti rugi. Hukuman pidana penjara juga bisa diterapkan kepada pihak yang melakukan pencemaran nama baik.

Dalam delik pencemaran nama

baik terdapat 3 hal penting yang harus diperhatikan yaitu : ${ }^{1}$

1. pertama delik dalam pencemaran nama baik merupakan delik yang bersifat subyektif yang artinya penilaian terhadap pencemaran sangat bergantung pada pihak yang diserang nama baiknya, oleh karenanya delik dalam pencemaran nama baik merupakan delik aduan yang hanya bisa diproses oleh pihak yang berwenang jika ada pengaduan dari korban pencemaran.

2. Kedua pencemaran nama baik merupakan delik penyebaran artinya substansi yang berisi pencemaran disebar luaskan kepada umum atau dilakukan di depan umum oleh pelaku.

3. Ketiga orang yang melakukan pencemaran nama baik dengan menuduh suatu hal yang dianggap menyerang nama baik seseorang atau pihak lain harus diberi kesempatan untuk membuktikan tuduhan itu.
Ketentuan pengaturan hukum dalam penghinaan bersifat delik aduan yaitu perkara penghinaan bisa terjadi jika ada pihak yang mengadu. Dalam hal masyarakat atau orang yang dirugikan atau yang merasa nama baiknya dicemarkan bisa mengadu pada pihak yang berwajib agar perkaranya bisa diselidiki yang berarti adalah apabila tidak ada aduan dari pihak yang merasa dirugikan perkara tersebut tidak akan diselidiki atau diusut.

\section{METODE PENELITIAN}

Penelitian ini adalah dengan menggunakan penelitian yuridis normatif, yaitu penelitian yang difokuskan pada penerapan kaidah-kaidah atau normanorma dalam hukum positif. ${ }^{2}$ Pendekatan Penelitian yang digunakan dalam penelitian yuridis normatif adalah menggunakan pendekatan case approach atau pendekatan kasus pada Pengadilan Tinggi Nomor 487/PID.SUS/2017/PT.MDN dan juga pendekatan perundang-undangan atau statue approach. Pendekatan perundangundangan (statute approach). Pendekatan ini melakukan pengkajian peraturan perundang-undangan yang berhubungan dengan pokok permasalahan, dan pendekatan perundang-undangan yang

\footnotetext{
2 Peter, Mahmud Marzuki. Penelitian Hukum. Kencana Media Pranada Media Grup. Jakarta. 2010, h. 17
} 
Jurnal Independent Fakultas Hukum

berkaitan dengan hukum pidana tentang pencemaran nama baik.

\section{HASIL PENELITIAN DAN PEMBAHASAN}

Pidana berasal dari kata straf (Belanda) yang biasanya juga disebut dengan istilah hukuman. Pidana lebih tepat didefinisikan sebagai suatu penderitaan yang sengaja dijatuhkan atau diberikan oleh negara pada seseorang atau beberapa orang sebagai akibat hukum atau sanksi atas perbuatan-perbuatan yang telah melanggar larangan hukum pidana. ${ }^{3}$

Tindak pidana menurut J.E Jonkers adalah perbuatan melawan hukum yang berhubungan dengan kesengajaan dan kesalahan yang dilakukan oleh orang yang dapat dipertanggung jawabkan. ${ }^{4}$

Pencemaran nama baik berdasarkan Kitab Undang-undang Hukum Pidana Pasal 310 ayat :

1. Menyerang nama baik seseorang dengan cara menuduhkan sesuatu hal.

2. Menyerang nama baik seseorang secara lisan maupun tertulis.

Undang-undang Informasi dan

Transaksi Elektronik Nomor 11 Tahun

2008 Jo Undang-undang 19 Tahun 2017.

Pasal 27 ayat (3) menyatakan bahwa : "setiap orang mentransmisikan ataupun membuat suatu Informasi Elektronik dan

\footnotetext{
${ }^{3}$ Mahrus, Ali. Dasar-dasar Hukum Pidana. Sinar Grafika. Jakarta. 2015.h.23

${ }^{4}$ Ibid. h.34
}

Dokumen Elektronik yang memiliki muatan "Penghinaan atau pencemaran nama baik"'.

Pasal 28 ayat (2) menyatakan bahwa :

"setiap orang dengan yang menyebarkan informasi yang menimbulkan rasa kebencian atau permusuhan antar individu/kelompok masyarakat tertentu, yang bersifat "SARA".

Pertimbangan hakim adalah hal-hal yang menjadi dasar atau yang dipertimbangkan hakim dalam memutus suatu perkara tindak pidana. Sebelum memutuskan sebuah perkara hakim harus memperhatikan setiap hal-hal penting dalam suatu persidangan.

Menurut Barda Nawawi Arief dalam mengambil suatu putusan dalam persidangan di pengadilan hakim dapat mempertimbangkan beberapa aspek yaitu.$^{5}$

1. Kesalahan pelaku tindak pidana.

2. Motif dan tuduhan dilakukannya suatu tindak pidana.

3. Cara melakukan tindak pidana.

4. Sikap baik pelaku tindak pidana.

5. Riwayat hidup dan sosial ekonomi.

6. Sikap dan tindakan pelaku sesudah melakukan tindak pidana.

7. Pengaruh pidana terhadap masa depan pelaku.

8. Pandangan masyarakat terhadap tindak pidana yang dilakukan oleh pelaku.

Hakim dalam memutus suatu perkara harus mempertimbangkan kebenaran secara yuridis (hukum) kebenaran filosofis

\footnotetext{
${ }^{5}$ Adami, Chazawi. Hukum Pidana Positif Penghinaan (Edisis Revisi). Media Nusa Creative. Malang. 2016., h.27
} 
Jurnal Independent Fakultas Hukum

(keadilan) dan sosiologis (kemasyarakatan)

agar bisa membuat suatu keputusan yang

adil dan bijaksana dengan tetap

mempertimbangkan dampak hukum dan

dampak yang terjadi di masyarakat.

Mengenai pertimbangan hakim pada pengadilan tingkat banding terdakwa yang telah melakukan tindak pidana pencemaran nama baik tersebut akan dikaji terlebih dahulu dan dipertimbangkan oleh majelis hakim apakah akan menerima permintaan banding dari terdakwa Togar Lubis setelah membaca putusan Pengadilan Negeri Stabat Nomor 852/Pid.Sus/2016/PN Stb tanggal 29 Mei 2017 yang amarnya berbunyi sebagai berikut :

1. Menyatakan terdakwa Togar Lubis, S.H. M.H., telah terbukti secara sah dan meyakinkan bersalah melakukan tindak pidana "DENGAN SENGAJA DAN TANPA HAK MEMBUAT DAPAT DIAKSES INFORMASI ELEKTRONIK DENGAN MUATAN PENGHINAAN";

2. Menjatuhkan pidana terhadap terdakwa tersebut dengan pidana penjara selama 5 (lima) bulan;

3. Menetapkan barang bukti berupa :

-7 (tujuh) unit lembar print out bernama TOGAR LUBIS K-Semar; -2 (dua) lembar status akun facebook an. TOGAR LUBIS dengan alamat website https//www.facebook.com/togar.lu bis;

- 5 (lima) piagam penghargaan dan ucapan terima kasih dalam rangka memeriahkan Hari Ulang Tahun Kabupaten Langkat yang ke-265;

Tetap terlampir dalam berkas perkara :

4. Membebani terdakwa untuk membayar biaya perkara sebesar Rp.2.000,- (dua ribu rupiah).

Akta permintaan banding yang dibaca pada tanggal 11 Juli Tahun 2017 Nomor 24/Akta.Pid/Bdg/2017/PN Stb permintaan tersebut telah diberitahukan dengan seksama kepada Jaksa Penuntut Umum akan tetapi dari pihak Jaksa Penuntut Umum tidak mengajukan kontra memori banding terhadap memori banding tersebut.

Menimbang, bahwa permintaan banding dari penasihat hukum terdakwa telah diajukan dalam tenggang waktu dan menurut tata cara serta syarat-syarat yang ditentukan oleh Undang-undang, oleh karena itu permohonan banding tersebut secara yuridis formal dapat diterima;

Menimbang, bahwa penasihat hukum terdakwa menolak putusan Pengadilan Negeri Stabat Nomor 852/Pid.Sus/2017/PN.Stb pada tanggal 29 Mei Tahun 2017 yang mengatakan bahwa majelis hakim telah melahirkan putusan yang subjektif dan sangat jauh rasa keadilan dengan alasan dalil sebagai berikut :

1. Majelis hakim yang memeriksa dan mengadili perkara tersebut tidak mempertimbangkan keterangan dari 
saksi dr. Sadikun Winato yang menerangkan sebelum dirinya berteman dengan terdakwa saksi tidak dapat mengakses atau melihat akun facebook terdakwa maka tidak mungkin saksi Jam'an saputra alias Jam maupun saksi Mas'ud alias dimas membaca potingan terdakwa di facebook miliknya;

2. Bahwa majelis hakim juga tidak mengutip dan mempertimbangkan keterangan saksi ahli bahasa Indonesia Dr. Wisman Hadi M.Hum yang menerangkan bila pernyataan itu, sesuai dengan realitas, kalimat-kalimat itu logis/benar;

3. Bahwa majelis hakim juga dalam putusan tersebut tidak mengutip atau mempertimbangkan keterangan saksi Jam'an Saputra alias jam bahwa kepada saksi Jam'an alias Jam, saksi Mas'ud alias dimas pernah bercerita bahwa pendidikannya adalah paket B dan paket $\mathrm{C}$;

4. Bahwa dipersidangan saksi Mas'ud alias Dimas juga tidak membantah postingan terdakwa di akun facebook miliknya maka berarti postingan terdakwa tersebut adalah fakta yang sesungguhnya;

5. Bahwa jika keterangan saksi Jam'an Saputa alias jam tersebut dipertimbangkan oleh majelis hakim maka postingan terdakwa di akun facebook miliknya adalah merupakan fakta dan bukan penghinaan atau pencemaran nama baik;

Dengan itu penasihat hukum

terdakwa memohon kepada majelis hakim tingkat banding yang mengadili perkara ini untuk memutuskan sebagai berikut :

1. Mengabulkan permohonan banding penasihat hukum terdakwa ini untuk seluruhnya;

2. Membatalkan putusan Pengadilan Negeri Stabat tanggal 29 Mei 2017 Nomor 852/Pid.Sus/2016/PN Stb;
3. Menyatakan terdakwa bebas dan lepas dari segala dakwaan dan tuntutan hukum (Vrijs praacht);

4. Memulihkan nama baik, harkat dan martabat terdakwa kedalam kedudukan semula;

5. Membebankan biaya yang timbul kepada negara.

Menimbang, bahwa memori banding penasihat hukum terdakwa majelis hakim tidak sependapat dengan alasan-alasan pada memori banding tersebut. Sebab pada postingan rangkaian kalimat tersebut "si sood itu kan pendidikan formalnya cuma tamat SD maka dia akan angkat orangorang yang menjadi anggota yang berpendidikan di bawahnya" maka dapat diketahui dengan jelas bahwa maksud atau tujuan dari terdakwa adalah untuk merendahkan dan meremehkann si sood karena pendidikannya suma tamat SD, dengan adanya kata-kata "cuma" maka tujuan kalimat tersebut adalah untuk merendahkan si sood apalagi dimuat di facebook yang dapat dibaca oleh khalayak umum.

Menimbang, bahwa setelah majelis hakim tingkat banding mempelajari dengan seksama berkas perkara yang dimohonkan oleh penasihat hukum dan salinan resmi dari putusan Pengadilan Negeri Statb Nomor 852/Pid.Sus/2016/PN.Stb maka majelis hakim berpendapat bahwa pertimbangan hukum majelis hakim tingkat pertama yang mendasari putusannya telah terbukti secara sah dan meyakinkan 
Jurnal Independent Fakultas Hukum

kesalahan terdakwa telah tepat dan benar.

Oleh karena itu majelis hakim tingkat banding dapat menyetujui dan mengambil alih sebagai pertimbangan hukum sendiri dalam memeriksa dan memutus perkara di tingkat banding.

Menimbang, bahwa dengan memperhatikan azas keadilan, kepatuhan dan kemanfaatan serta hal-hal yang memberatkan dan meringkan sebagaimana dalam putusan majelis hakim tingkat pertama menurut majelis hakim tingkat banding bahwa pidana yang dijatuhkan oleh majelis hakim tingkat pertama telah tepat dan sesuai dengan kesalahan terdakwa serta telah memnuhi rasa keadilan dalam masyarakat.

Menimbang, bahwa berdasarkan pertimbangan tersebut diatas, maka putusan Pengadilan Negeri Stabat Nomor 852/Pid.Sus/2016/PN.Stb, tanggal 29 Mei Tahun 2017 yang dimintakan banding dapat dipertahankan dan dikuatkan ditingkat banding.

Menimbang, bahwa berdasarkan Pasal 222 ayat (1) Kitab Undang-undang Hukum Acara Pidana oleh karena terdakwa tetap dinyatakan bersalah dan dijatuhi pidana maka kepadanya harus dibebankan untuk membayar biaya perkara dalam kedua tingkat peradilan.
Berdasarkan amar putusannya, majelis hakim menyatakan bahwa terdakwa terbukti bersalah dan memutus mengadili :

1. Menerima permintaan banding dari terdakwa tersebut;

2. Menguatkan putusan Pengadilan Negeri Stabat Nomor 852/Pid.Sus/2016/PN.Stb tanggal 29 Mei 2017, yang dimintai banding;

3. Membebankan biaya perkara kepada terdakwa dalam kedua tingkat peradilan, untuk tingkat banding sebesar Rp.2.500,- (dua ribu lima ratus rupiah);

Sebelumnya, perlu dibedakan antara diseminasi informasi yang bermuatan pencemaran nama baik, serta yang berkaitan dengan SARA. Dalam UU ITE, ketentuan penghinaan dan pencemaran nama baik diatur dalam Pasal 27 ayat (3) UU ITE, sedangkan ketentuan SARA diatur dalam Pasal 28 ayat (2) UU ITE.

Berdasarkan Pasal 43 ayat (1) UU 19/2016, delik-delik tersebut dapat dilaporkan atau diadukan kepada Penyidik POLRI atau kepada Penyidik Pegawai Negeri Sipil Informasi dan Transaksi Elektronik (“PPNS ITE”). Sanksi dapat dijatuhkan apabila pelaku memenuhi seluruh unsur dan telah melalui proses peradilan pidana yang berdasarkan pada ketentuan hukum acara pidana.

Pasal yang mengatur mengenai penghinaan, pencemaran nama baik dan ujaran kebencian berdasarkan SARA diatur 
Jurnal Independent Fakultas Hukum

dalam Pasal 27 ayat (3) UU ITE dan Pasal 28 ayat (2) UU ITE:

Bunyi Pasal 27 ayat (3) UU ITE adalah sebagai berikut:

Setiap Orang dengan sengaja dan tanpa hak mendistribusikan dan latau mentransmisikan dan/ atau membuat dapat diaksesnya Informasi Elektronik dan/atau Dokumen Elektronik yang memiliki muatan penghinaan dan/atau pencemaran nama baik.

Sedangkan bunyi Pasal 28 ayat (2)

UU ITE adalah sebagai berikut:

Setiap Orang dengan sengaja dan tanpa hak menyebarkan informasi yang ditujukan untuk menimbulkan rasa kebencian atau permusuhan individu dan/atau kelompok masyarakat tertentu berdasarkan atas suku, agama, ras, dan antargolongan (SARA).

Ancaman pidana bagi orang yang melanggar Pasal 27 ayat (3) UU ITE ini diatur dalam Pasal 45 ayat (3) UU 19/2016, yang berbunyi:

Setiap Orang yang dengan sengaja dan tanpa hak mendistribusikan dan/atau mentransmisikan dan/atau membuat dapat diaksesnya Informasi Elektronik dan/atau Dokumen Elektronik yang memiliki muatan penghinaan dan/atau pencemaran nama baik sebagaimana dimaksud dalam Pasal 27 ayat (3) dipidana dengan pidana penjara paling lama 4 (empat) tahun dan/atau denda paling banyak Rp750.000.000,00 (tujuh ratus lima puluh juta rupiah).

Kemudian ancaman pidana bagi orang yang melanggar ketentuan Pasal 28 ayat (2) UU ITE, adalah sebagaima diatur dalam Pasal 45A ayat (2) UU 19/2016, yakni:

Setiap Orang yang dengan sengaja dan tanpa hak menyebarkan informasi yang ditujukan untuk menimbulkan rasa kebencian atau permusuhan individu dan/atau kelompok masyarakat tertentu berdasarkan atas suku, agama, ras, dan antargolongan (SARA) sebagaimana dimaksud dalam Pasal 28 ayat (2) dipidana dengan pidana penjara paling lama 6 (enam) tahun dan/atau denda paling banyak Rp1.000.000.000,00 (satu miliar rupiah).

Berdasarkan Putusan Mahkamah

Konstitusi Nomor 50/PUU-VI/2008 dan Nomor 2/PUU-VII/2009, tindak pidana penghinaan dan pencemaran nama baik dalam bidang Informasi Elektronik dan Transaksi Elektronik bukan semata-mata sebagai tindak pidana umum, melainkan sebagai delik aduan. Penegasan mengenai delik aduan dimaksudkan agar selaras dengan asas kepastian hukum dan rasa keadilan masyarakat.

\section{KESIMPULAN DAN SARAN}

Dasar pertimbangan hukum hakim dalam memutus perkara banding tindak pidana pencemaran nama baik dalam kasus tersebut adalah dengan mengkaji posisi kasus, dakwaan dari penuntut umum dan 
Jurnal Independent Fakultas Hukum

tuntutan dari penuntut umum serta fakta yang terbukti bahwasanya terdakwa telah melakukan tindak pidana pencemaran nama baik melalui pembuktian berdasarkan alatalat bukti yang sah dan dengan memperhatikan azas keadilan, kepatuhan dan kemanfaatan serta hal-hal yang memberatkan dan meringankan terdakwa. Majelis hakim menyatakan bahwa terdakwa terbukti bersalah dan menguatkan putusan Pengadilan Negeri Stabat yang dimintai banding. Apabila ada kalimat atau kata yang menjelekkan dan mencemari nama baik orang lain, melontarkan kalimat yang bersifat menyinggung SARA, serta memprovokasi pengguna media sosial dapat dipidana bersarkan Pasal 27 ayat (3) dan Pasal 28 ayat (2) UU ITE.

Ancama pidana jika melakukan tindakan mencemarkan nama baik seseorang adalah pidana penjara paling lama 4 (empat) tahun dan/atau denda paling banyak Rp 750 juta. Tindakan ini adalah merupakan delik aduan. Sehingga untuk dapat dipidana dengan pasal ini maka harus dengan aduan korban pada pejabat yang berwenang menerima pengaduan yaitu Penyidik POLRI atau kepada PPNS ITE.

Sedangkan tindakan yang bersifat menyinggung SARA juga dapat dipidana dengan penjara paling lama 6 (enam) tahun dan/atau denda paling banyak Rp 1 miliar.
Tindakan ini dapat dilaporkan pada Penyidik POLRI atau kepada PPNS ITE.

\section{DAFTAR PUSTAKA}

Adami, Chazawi. Pelajaran Hukum Pidana Bag.1. Stelsesl Pidana, Tindak Pidana, Dasar Penia dan Pidana, Pembera tandan Peringanan, Kejahatan Aduan, Perbarengan dan Ajaran Kausalitas, cet.5 PT Raja GrafindoPersada. Jakarta. 2011. Hukum Pidana Positif Penghinaan (Edisis Revisi). Media Nusa Creative. Malang. 2016. Ahmad, Ali. Menguak Teori Hukum (Legal Theory) dan teori Peradilan (Judicial Prudence), Kencana Prenada Media Grup. Jakarta. 2010.

Mahrus, Ali. Dasar-dasar Hukum Pidana. Sinar Grafika. Jakarta. 2015.

Peter, Mahmud Marzuki. Penelitian Hukum. Kencana Media Pranada Media Grup. Jakarta. 2010. 